\title{
Paleoclimate in continental northwestern Europe during the Eemian and early Weichselian (125-97 ka): insights from a Belgian speleothem
}

\author{
Stef Vansteenberge ${ }^{1}$, Sophie Verheyden ${ }^{1,2}$, Hai Cheng ${ }^{3,4}$, R. Lawrence Edwards ${ }^{4}$, Eddy Keppens ${ }^{1}$, and \\ Philippe Claeys ${ }^{1}$ \\ ${ }^{1}$ Earth System Science Group, Analytical-, Environmental- \& Geo-Chemistry, Vrije Universiteit Brussel, Brussels, Belgium \\ ${ }^{2}$ Royal Belgian Institute for Natural Sciences, Brussels, Belgium \\ ${ }^{3}$ Institute of Global Environmental Change, Xi' an Jiaotong University, Xi'an, China \\ ${ }^{4}$ Department of Earth Sciences, University of Minnesota, Minneapolis, USA
}

Correspondence to: Stef Vansteenberge (svsteenb@vub.ac.be)

Received: 1 February 2016 - Published in Clim. Past Discuss.: 8 February 2016

Revised: 30 May 2016 - Accepted: 15 June 2016 - Published: 5 July 2016

\begin{abstract}
The last interglacial serves as an excellent time interval for studying climate dynamics during past warm periods. Speleothems have been successfully used for reconstructing the paleoclimate of last interglacial continental Europe. However, all previously investigated speleothems are restricted to southern Europe or the Alps, leaving large parts of northwestern Europe undocumented. To better understand regional climate changes over the past, a larger spatial coverage of European last interglacial continental records is essential, and speleothems, because of their ability to obtain excellent chronologies, can provide a major contribution. Here, we present new, high-resolution data from a stalagmite (Han9) obtained from the Han-sur-Lesse Cave in Belgium. Han9 formed between 125.3 and $\sim 97 \mathrm{ka}$, with interruptions of growth occurring at 117.3-112.9 and 106.6-103.6 ka. The speleothem was investigated for its growth, morphology and stable isotope $\left(\delta^{13} \mathrm{C}\right.$ and $\left.\delta^{18} \mathrm{O}\right)$ composition. The speleothem started growing relatively late within the last interglacial, at $125.3 \mathrm{ka}$, as other European continental archives suggest that Eemian optimum conditions were already present during that time. It appears that the initiation of Han-9 growth is caused by an increase in moisture availability, linked to wetter conditions around $125.3 \mathrm{ka}$. The $\delta^{13} \mathrm{C}$ and $\delta^{18} \mathrm{O}$ proxies indicate a period of relatively stable conditions after $125.3 \mathrm{ka}$; however, at $120 \mathrm{ka}$ the speleothem $\delta^{18} \mathrm{O}$ registered the first signs of regionally changing climate conditions, being a modification of ocean source $\delta^{18} \mathrm{O}$ linked to an increase in ice volume
\end{abstract}

towards the Marine Isotope Stage (MIS) 5e-5d transition. At $117.5 \mathrm{ka}$, drastic vegetation changes are recorded by Han$9 \delta^{13} \mathrm{C}$ immediately followed by a cessation of speleothem growth at $117.3 \mathrm{ka}$, suggesting a transition to significantly dryer conditions. The Han-9 record covering the early Weichselian displays larger amplitudes in both isotope proxies and changes in stalagmite morphology, evidencing increased variability compared to the Eemian. Stadials that appear to be analogous to those in Greenland are recognized in Han-9, and the chronology is consistent with other European (speleothem) records. Greenland Stadial 25 is reflected as a cold/dry period within Han-9 stable isotope proxies, and the second interruption in speleothem growth occurs simultaneously with Greenland Stadial 24.

\section{Introduction}

The last interglacial (LIG) period is known as the time interval before the last glacial period during which temperatures were similar to or higher than those of the Holocene period and present day (Otto-Bliesner et al., 2013). In marine sediment cores, the LIG is defined as Marine Isotope Stage (MIS) 5e (Shackleton, 1969). The start and end of the MIS 5e period are conventionally set at 130 and $116 \mathrm{ka}$, respectively, based on marine records (e.g., Martinson et al., 1987). The expression of the LIG in continental western Europe is defined as the Eemian, although it does not coincide precisely with the 
isotopically constrained MIS 5e (Otvos, 2015). Given the ongoing debate about the LIG nomenclature, clarification about the terms used in this manuscript is required. This study focuses on speleothem archives; thus the terms "Eemian" and "Weichselian" are preferred in the context of European continental paleoclimate. The Eemian is defined as the optimum or acme LIG climate conditions (the "sensu stricto" definition). Subsequent to the Eemian, the Weichselian starts, with the early Weichselian in continental records corresponding with the time equivalent of MIS 5d-5a. "Glacial inception" is considered to be informal and only marks the Eemian-early Weichselian transition.

The term Eemian was originally introduced by P. Harting in 1875 and was characterized by the occurrence of warmwater mollusks in marine sediments of the Eem River valley, near Amsterdam, the Netherlands. Nowadays, the Eemian is mostly interpreted as an interval of warmer climate associated with the spread of temperate mixed forests in areas with similar vegetation to today (Kukla et al., 2002). However, the Eemian is also known to be a diachronous unit (Kukla et al., 2002; Wohlfarth et al., 2013) with a longer duration of up to $20 \mathrm{ka}$, from 130 to $110 \mathrm{ka}$, in southern Europe as evidenced by pollen records (Sanchez Goñi et al., 1999; Tzedakis et al., 2003). The LIG period exhibited global mean temperatures (GMT) 1.5 to $2{ }^{\circ} \mathrm{C}$ higher than the pre-anthropogenic average together with peak eustatic sea levels that were between 5.5 and $9 \mathrm{~m}$ higher than present (Dutton and Lambeck, 2012). Therefore, the LIG gained a lot of attention from both paleoclimate and climate-modeling communities for studying a warmer climate state and potential future sea-level rise (Loutre et al., 2014; Goelzer et al., 2015), even though the present-day configuration of Earth's orbital forcing parameters is different (Berger and Loutre, 2002). Following the Eemian, climate went into a glacial mode known as the last glacial cycle, or the Weichselian in the western European continental terminology, which lasted until the Holocene. A major feature of climate variability during the last glacial is the occurrence of millennial-scale, rapid cold-warm-cold cycles, known as Dansgaard-Oeschger $(\mathrm{D} / \mathrm{O})$ events (Bond et al., 1993). These $\mathrm{D} / \mathrm{O}$ cycles are expressed as alternating Greenland stadial (GS) and interstadial (GIS) phases in Greenland ice cores (Dansgaard et al., 1993; NGRIP members, 2004), and they also have affinity with Atlantic cold events registered in sea surface temperature proxies (McManus et al., 1994). Some of the stadials are also associated with an increased flux of ice-rafted debris (IRD) in the North Atlantic Ocean (McManus et al., 1994). These events have been linked to changes in the strength and shifts in the northwards extent of Atlantic Meridional Overturning Circulation (AMOC) (Broecker et al., 1985). The exact cause of such changes in the AMOC mode is still debated. Nevertheless, according to Barker et al. (2015), it is more likely a nonlinear response of a gradual cooling of the climate than a result of enhanced freshwater input by iceberg calving, as previously proposed by Bond et al. (1995) and van Krev- eld et al. (2000). Likewise, continental pollen records extracted from cores of Eifel Maar lakes (Sirocko et al., 2005) or peat bogs in the Vosges region, France (Woillard, 1978; de Beaulieu and Reille, 1992; de Beaulieu, 2010), have recorded changes in pollen assembly, attributed to $\mathrm{D} / \mathrm{O}$ variability. So far, up to $26 \mathrm{GSs}$ have been identified in ice cores, with GS 26 recognized as corresponding with the end of the Eemian interglacial period (NGRIP members, 2004).

Speleothems are ideal for late Quaternary paleoclimate studies because of their ability to obtain accurate chronologies with $\mathrm{U} / \mathrm{Th}$ dating of up to $600 \mathrm{ka}$ and their potential to yield high-resolution (up to seasonal scale) paleoclimate records (Fairchild and Baker, 2012). The speleothem records covering the Eemian and early Weichselian in Europe have provided detailed paleoclimate reconstructions (Genty et al., 2013). Several speleothem stable isotope proxies from $\mathrm{Eu}-$ rope record optimum climatic conditions during the Eemian (Meyer et al., 2008; Couchoud et al., 2009) and D/O climate events during the early Weichselian (Bar-Matthews et al., 1999; Drysdale et al., 2007; Boch et al., 2011). Yet so far, all records covering that time period are located in southern Europe (Italy, southern France, Levant) or the Alps. This study presents a new high-resolution speleothem dataset from Belgium that expands the European coverage of last interglacial speleothem archives northwards.

Earlier chronostratigraphic work on speleothem deposits and detrital sediments within Belgian caves marked the presence of glacial-interglacial cycles, with speleothem formation restricted to interglacial periods, when warm and wet climates favored growth. Detrital sediments settle in colder periods, with river deposits in cold, wet periods and reworked loams during cold, dry periods (Quinif, 2006). From the 1980s onwards, speleothems covering MIS 9 to 1 have been found in various Belgian caves (Bastin and Gewelt, 1986; Gewelt and Ek, 1988). Quinif and Bastin (1994) analyzed an Eemian flowstone from the Han-sur-Lesse Cave for its pollen composition and demonstrated that vegetation above the cave area reflects interglacial climate optimum conditions around $130 \pm 10 \mathrm{ka}$. However, the dating of this material contains large uncertainties related to the alpha spectrometric methodology used. This study focuses on a recently obtained speleothem, Han-9 from the Han-sur-Lesse Cave in southern Belgium. This stalagmite was analyzed to better constrain (1) the chronology of Eemian optimum conditions in Belgium and (2) the occurrence and signature of millennial-scale climate variability $(\mathrm{D} / \mathrm{O})$ over northwestern Europe during the early Weichselian.

\section{Han-sur-Lesse Cave: geology and cave parameters}

The Han-sur-Lesse Cave system is the largest known subterranean karst network in Belgium, with a total length of $\sim 10 \mathrm{~km}$. It is located within the Calestienne, a SW-NE- 


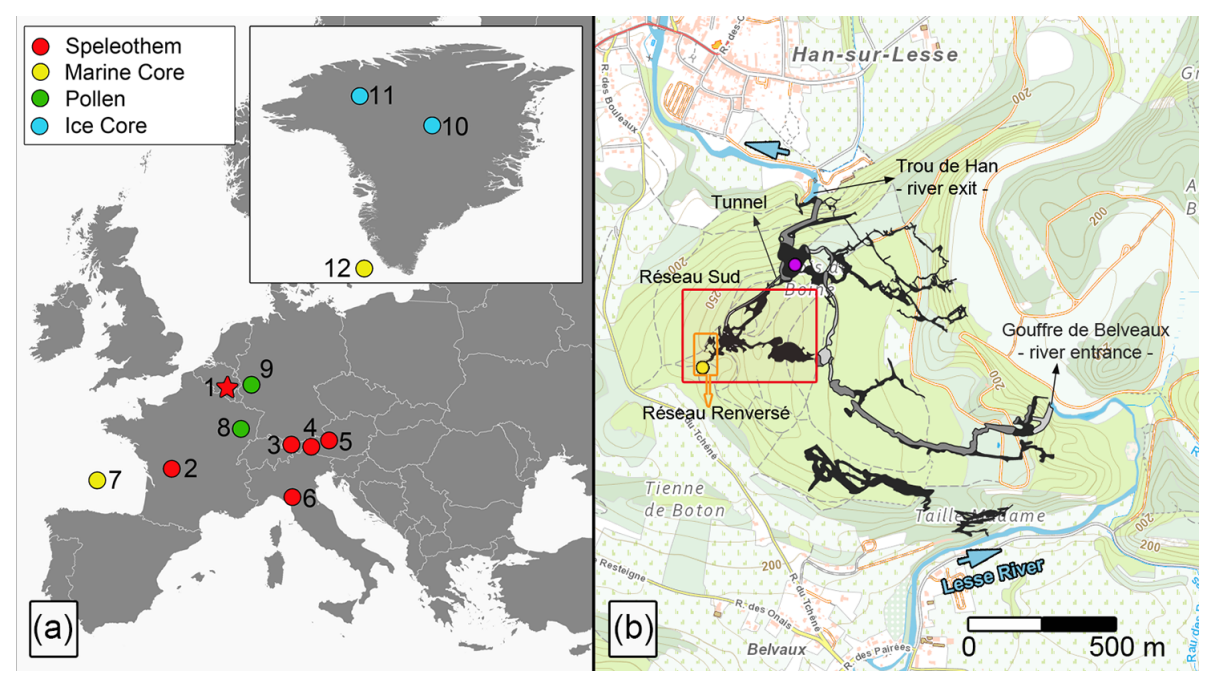

Figure 1. (a) Location of the Han-sur-Lesse Cave site (red star) and other records mentioned in this study: (1) Han-sur-Lesse; (2) BourgeoisDelaunay Cave (Couchoud et al., 2009); (3) Hölloch Cave (Moseley et al., 2015); (4) Spannagel Cave (Hölzkamper et al., 2004); (5) Entrische Kirche Cave (Meyer et al., 2008); (6) Corchia Cave (Drysdale et al., 2009); (7) MD04-2548 (Sanchez-Goñi et al., 2012); (8) La Grande Pile (Woillard, 1978); (9) Eifel Maar (Sirocko et al., 2005); (10) NGRIP (NGRIP Members, 2004); (11) NEEM (NEEM community, 2013); and (12) MD03-2664 (Irvali et al., 2012). (b) Topographic map of the study area (source: NGI Belgium). The Han-sur-Lesse Cave system is plotted in black. The sampling site of Han-9 is marked by the yellow dot; the purple dot represents the location of cave monitoring by Van Rampelbergh et al. (2014). The Réseau Sud and the Réseau Renversé are shown by the red and orange box, respectively. For further explanation, see text. Figure adapted from Quinif (2006).

trending superficial limestone belt of Middle Devonian age. After deposition, these Paleozoic sediments underwent Hercynian folding followed by Mesozoic erosion. The current hydrographic network was established during the Neogene and Pleistocene, by erosion into these folded belts (Quinif, 2006). The cave system was formed within the Massif de Boine, part of an anticline structure consisting of middle to late Givetian reefal limestones, by a meander shortcut of the Lesse River (Fig. 1b). The thickness of the epikarst zone above the cave is estimated to be around $40 \mathrm{~m}$.

The area of the Han-sur-Lesse Cave is located $\sim 200 \mathrm{~km}$ inland at an elevation of $200 \mathrm{~m}$ above sea level (Fig. 1) and is marked by a maritime climate with cool summers and mild winters. For the period 1999-2013, average year temperature above the cave was $10.2^{\circ} \mathrm{C}$, and average yearly rainfall amount $820 \mathrm{~mm} \mathrm{yr}^{-1}$. The amount of precipitation does not follow a seasonal distribution (Royal Meteorological Institute, RMI). The dominant moisture source in northwestern Europe is the North Atlantic Ocean, and this remains constant throughout the year (Gimeno, 2010). Modern $\delta^{18} \mathrm{O}$ of rainfall seasonally varies between $-17 \%$ in winter and $-4 \%$ in summer (Van Rampelbergh et al., 2014). The area above the cave mainly consists of $\mathrm{C} 3$ type vegetation with Corylus, Fagus and Quercus trees, and as a natural reserve it has been protected from direct human influence for over 50 years (Timperman, 1989). The Lesse River enters the cave system at the Gouffre de Belvaux and exits at the Trou de Han approximately $24 \mathrm{~h}$ later. The Han- 9 stalagmite was collected within the Réseau Renversé, which is the most dis- tal part of the Réseau Sud (Fig. 1b). The natural connection between the Réseau Sud and other parts of the Han-surLesse Cave is fully submerged, but in 1960 an artificial tunnel was established facilitating access (Timperman, 1989). When water of the Lesse River is high, part of the stream is redirected through the Réseau Sud, but it does not reach the Réseau Renversé (Bonniver, 2010). Earlier studies have shown that cave drip waters are mostly supplied by diffuse flow through the host rock (Bonniver, 2011; Van Rampelbergh et al., 2014). The Han-sur-Lesse Cave is partly accessible for tourists, but because of the difficult access the Réseau Sud is protected from any anthropogenic influence. Temperature logging for 6 months with an interval of $2 \mathrm{~h}$ in the Réseau Renversé shows an average cave temperature of $9.45^{\circ} \mathrm{C}$ with a standard deviation $<0.02^{\circ} \mathrm{C}$, which reflects the average temperature of $9.2^{\circ} \mathrm{C}$ above the cave for 2013 . Minimum and maximum temperatures were 9.39 and $9.51^{\circ} \mathrm{C}$, respectively (C. Burlet, personal communication, 2014). This shows that the temperature in the Réseau Renversé is constant through the year and that it reflects the average temperature above the cave. In contrast, recent cave monitoring in more ventilated parts of the cave indicated a temperature seasonality of $3{ }^{\circ} \mathrm{C}$ (Van Rampelbergh et al., 2014). For the Réseau Renverse, there are no indications that cave morphology changed significantly since the last interglacial. Han-9, the stalagmite presented in this study, was deliberately sampled because it was already broken into three parts, so no other speleothems had to be destroyed. Although the sample was broken, it was 


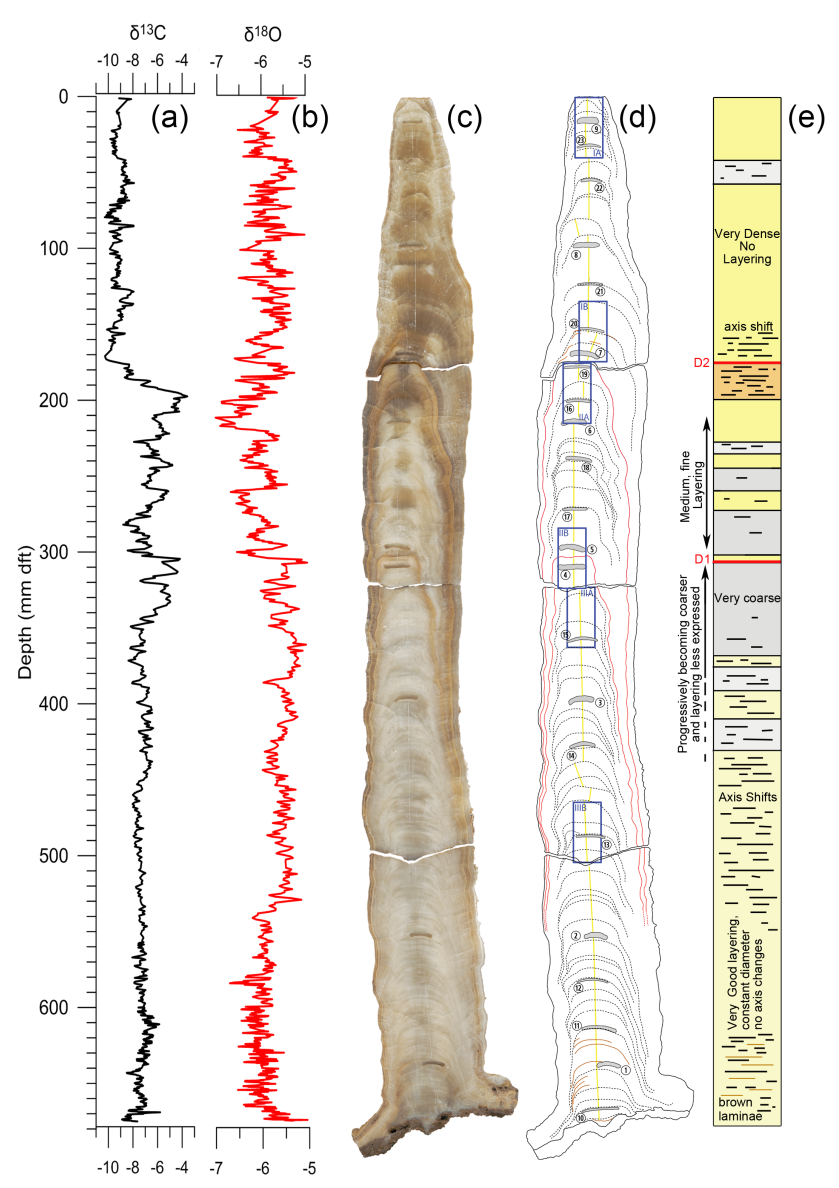

Figure 2. Descriptive image of Han-9 (a) $\delta^{13} \mathrm{C}$ plotted against distance from top in $\mathrm{mm}$; (b) $\delta^{18} \mathrm{O}$ plotted against distance from top in $\mathrm{mm}$; (c) high-resolution scan of the polished slabs; (d) interpretation of the internal structure of the speleothem. Dashed lines: distinctive layers; red lines: growth discontinuities; grey areas: dating samples, where numbers refer to the samples in Table 1; yellow line: central axis (sample axis); blue boxes: thin section locations; brown lines: detrital material. (e) Stratigraphic log: colors indicate the presence of dense calcite (yellow) or coarse calcite (grey); more intense color: denser/coarser compared to lighter colored parts. The visual expression of layering is indicated with the dashes in the log. Further description of the log can be found in the figure and text.

still in situ. The candle-shaped stalagmite has a length of $70 \mathrm{~cm}$ (Fig. 2c-e).

The Han-sur-Lesse Cave has received scientific attention in the last decades, making it the best-understood cave system in Belgium. This includes detailed hydrographic studies (Bonniver et al., 2010) and extended cave-monitoring surveys (Verheyden et al., 2008; Van Rampelbergh et al., 2014), leading to successful paleoclimate reconstructions on Holocene speleothems down to seasonal scale (Verheyden et al., 2006, 2012, 2014; Van Rampelbergh et al., 2015). The elaborate cave monitoring (Fig. 1b) has provided a solid foundation for understanding the cave system and for interpreting its paleoclimate records, even back to $\sim 120 \mathrm{ka}$.

\section{Methods and analytical procedures}

All ages were acquired by using U/Th dating at the University of Minnesota Earth Sciences Department, Minneapolis. Nine samples were analyzed in 2013 , and an additional batch of 14 samples was dated in 2015 to further improve the age-depth model with additional sampling locations selected based on the preliminary age model and the stable isotope $\left(\delta^{13} \mathrm{C}\right.$ and $\left.\delta^{18} \mathrm{O}\right)$ data (Fig. 2d). For all U/Th analyses, $150-200 \mathrm{mg}$ of speleothem calcite was milled and analyzed with a Neptune multiple-collector plasma source mass spectrometer (MC-ICP-MS) from Thermo Scientific. Ages were corrected assuming an initial ${ }^{230} \mathrm{Th} /{ }^{232} \mathrm{Th}$ atomic ratio of $4.4 \pm 2.2 \times 10^{-6}$. The age datum is $1950 \mathrm{CE}$. For additional information about the applied method, see Edwards et al. (1987), Shen et al. (2012) and Cheng et al. (2013) and references therein. Age-depth modeling was carried out using the StalAge algorithm of Scholz and Hoffmann (2011). All depths are expressed in "mm dft", with dft being "distance from top".

All stable isotope analysis were carried out at the Stable Isotope Laboratory, Vrije Universiteit Brussel. A total of 1118 samples were drilled with a Merchantek MicroMill, a computer-steered drill mounted on a microscope. Samples were taken along the central growth axis to avoid possible effects of evaporation during calcite deposition (Fairchild et al., 2006). For all samples, tungsten carbide dental drill bits with a diameter of $300 \mu \mathrm{m}$ from Komet were used. As a function of the growth rate, 1000,500 and $250 \mu \mathrm{m}$ sampling resolutions were applied in order to maintain a more or less equal resolution in the time domain. For sample locations, see Fig. 2 d. Samples were kept at $50{ }^{\circ} \mathrm{C}$ prior to analysis to avoid contamination. $\delta^{13} \mathrm{C}$ and $\delta^{18} \mathrm{O}$ isotope measurements were performed on a Perspective IRMS from $\mathrm{Nu}$ Instruments, coupled to a Nucarb automated carbonate preparation system and a minor amount $(<100)$ on a Kiel III device coupled to a Delta plus XL from Thermo Scientific. Two samples of the in-house standard MAR-2(2), which is made from Marbella limestone and has been calibrated against the international standard NBS-19 (Friedman et al., 1982), were measured every 10 samples to correct for instrumental drift. Reported values for the MAR-2(2) are $0.13 \%$ o Vienna Pee Dee Belemnite (VPDB) for $\delta^{18} \mathrm{O}$ and $3.41 \%$ VPDB for $\delta^{13} \mathrm{C}$. Analytical uncertainties in standards from individual batches were $\leq 0.05 \%$ for $\delta^{13} \mathrm{C}$ and $\leq 0.08 \%$ for $\delta^{18} \mathrm{O}$ on the Nu Instruments setup. At regular intervals, a replicate sample was measured in a different batch to check for the reproducibility of the analytical method. Outliers were manually detected, removed and remeasured if sufficient material was present. In addition, six $30 \mu \mathrm{m}$ thin sections were taken along the growth transect (Fig. 2d). 
Table 1. U/Th measurements of the Han-9 stalagmite (University of Minnesota). Samples are arranged in stratigraphic order, and those in bold indicate results acquired in 2013 . U decay constants: $\lambda_{238}=1.55125 \times 10^{-10}$ (Jaffey et al., 1971) and $\lambda_{234}=2.82206 \times 10^{-6}($ Cheng et al., 2013). Th decay constant: $\lambda_{230}=9.1705 \times 10^{-6}$ (Cheng et al., 2013). Corrected ${ }^{230} \mathrm{Th}$ ages assume the initial ${ }^{230} \mathrm{Th} /{ }^{232} \mathrm{Th}$ atomic ratio of $4.4 \pm 2.2 \times 10^{-6}$. Those are the values for a material at secular equilibrium, with the bulk earth ${ }^{232} \mathrm{Th} /{ }^{238} \mathrm{U}$ value of 3.8 . The errors are arbitrarily assumed to be $50 \%$.

\begin{tabular}{|c|c|c|c|c|c|c|c|c|c|c|}
\hline $\begin{array}{l}\text { Sample } \\
\text { number }\end{array}$ & $\begin{array}{r}\text { DFT } \\
(\mathrm{mm})\end{array}$ & $\begin{array}{l}{ }^{238} \mathrm{U} \\
(\mathrm{ppb})\end{array}$ & $\begin{array}{r}{ }^{232} \mathrm{Th} \\
(\mathrm{ppt})\end{array}$ & $\begin{array}{r}{ }^{230} \mathrm{Th} /{ }^{232} \mathrm{Th} \\
\left(\text { atomic } \times 10^{-6}\right)\end{array}$ & $\begin{array}{r}\delta^{234} U^{*} \\
\text { (measured) }\end{array}$ & $\begin{array}{r}{ }^{230} \mathrm{Th} /{ }^{238} \mathrm{U} \\
\text { (activity) }\end{array}$ & $\begin{array}{r}{ }^{230} \text { Th Age (yr) } \\
\text { (uncorrected) }\end{array}$ & $\begin{array}{r}{ }^{230} \mathrm{Th} \text { Age }(\mathrm{yr}) \\
(\text { corrected })\end{array}$ & $\begin{array}{r}\delta^{234} \mathrm{U}_{\text {Initial }}{ }^{* *} \\
(\text { corrected })\end{array}$ & $\begin{array}{r}{ }^{230} \text { Th Age }(\mathrm{yr} \mathrm{BP}) * * * \\
(\text { corrected })\end{array}$ \\
\hline DAT-10 & 668 & $531.5 \pm 0.6$ & $1693 \pm 34$ & $6077 \pm 122$ & $622,5 \pm 1.5$ & $1.1739 \pm 0.0016$ & $124854 \pm 363$ & $124805 \pm 364$ & $885 \pm 2$ & $124740 \pm 364$ \\
\hline DAT-1 & 639 & $475.3 \pm 0.4$ & $6419 \pm 128$ & $1417 \pm 29$ & $606 \pm 3$ & $1.1608 \pm 0.0027$ & $124781 \pm 653$ & $124569 \pm 669$ & $862 \pm 4$ & $124506 \pm 669$ \\
\hline DAT-11 & 614.6 & $227.6 \pm 0.2$ & $413 \pm 8$ & $11096 \pm 223$ & $704.0 \pm 1.6$ & $1.2220 \pm 0.0013$ & $122075 \pm 304$ & $122049 \pm 305$ & $993 \pm 2$ & $121984 \pm 305$ \\
\hline DAT- 12 & 581.5 & $289.7 \pm 0,2$ & $1597 \pm 32$ & $3563 \pm 71$ & $675.2 \pm 1.5$ & $1.1911 \pm 0.0014$ & $120625 \pm 304$ & $120542 \pm 310$ & $949 \pm 2$ & $120477 \pm 310$ \\
\hline DAT-2 & 554 & $370.5 \pm 0.3$ & $213 \pm 4$ & $33652 \pm 692$ & $661 \pm 3$ & $1.1759 \pm 0.0029$ & $119934 \pm 589$ & $119925 \pm 589$ & $927 \pm 4$ & $119862 \pm 589$ \\
\hline DAT-13 & 484.2 & $390.1 \pm 0.4$ & $1420 \pm 28$ & $5246 \pm 105$ & $637.7 \pm 1.6$ & $1.1583 \pm 0.0015$ & $119971 \pm 331$ & $119915 \pm 333$ & $895 \pm 2$ & $119850 \pm 333$ \\
\hline DAT-14 & 426 & $337.7 \pm 0.3$ & $243 \pm 5$ & $26740 \pm 539$ & $656.3 \pm 1.5$ & $1.1679 \pm 0.0013$ & $119179 \pm 289$ & $119168 \pm 289$ & $919 \pm 2$ & $119103 \pm 289$ \\
\hline DAT-3 & 397 & $373.4 \pm 0.3$ & $681 \pm 14$ & $10480 \pm 211$ & $650 \pm 2$ & $1.1596 \pm 0.0027$ & $118564 \pm 539$ & $118536 \pm 539$ & $908 \pm 3$ & $118473 \pm 539$ \\
\hline DAT-15 & 356 & $636.0 \pm 0.7$ & $1406 \pm 28$ & $8600 \pm 172$ & $648.9 \pm 1.5$ & $1.1533 \pm 0.0014$ & $117661 \pm 306$ & $117627 \pm 307$ & $904 \pm 2$ & $117562 \pm 307$ \\
\hline DAT-4 & 311 & $226.6 \pm 0.3$ & $1735 \pm 35$ & $2526 \pm 51$ & $667 \pm 3$ & $1.1727 \pm 0.0036$ & $118596 \pm 727$ & $118481 \pm 731$ & $932 \pm 5$ & $118418 \pm 731$ \\
\hline DAT-5 & 297 & $396.8 \pm 0.4$ & $563 \pm 11$ & $13324 \pm 269$ & $677 \pm 2$ & $1.1456 \pm 0.0027$ & $112964 \pm 512$ & $112942 \pm 512$ & $931 \pm 4$ & $112879 \pm 512$ \\
\hline DAT-17 & 271 & $213.5 \pm 0.1$ & $1647 \pm 33$ & $2460 \pm 49$ & $692.3 \pm 1.4$ & $1.1511 \pm 0.0011$ & $112045 \pm 237$ & $111930 \pm 251$ & $949 \pm 2$ & $111865 \pm 251$ \\
\hline DAT-18 & 238.5 & $239.0 \pm 0.2$ & $208 \pm 4$ & $21967 \pm 446$ & $709.8 \pm 1.6$ & $1.1594 \pm 0.0012$ & $111337 \pm 254$ & $111324 \pm 254$ & $972 \pm 2$ & $111259 \pm 254$ \\
\hline DAT-6 & 214 & $216.2 \pm 0.3$ & $939 \pm 19$ & $4315 \pm 87$ & $691 \pm 3$ & $1.1365 \pm 0.0035$ & $109887 \pm 637$ & $109822 \pm 638$ & $943 \pm 4$ & $109759 \pm 638$ \\
\hline DAT-16 & 201 & $158.8 \pm 0.1$ & $386 \pm 8$ & $7695 \pm 155$ & $680.1 \pm 1.5$ & $1.1334 \pm 0.0012$ & $110663 \pm 245$ & $110627 \pm 246$ & $929 \pm 2$ & $110562 \pm 246$ \\
\hline DAT-19 & 179.5 & $179.8 \pm 0.1$ & $3158 \pm 63$ & $1064 \pm 21$ & $711.7 \pm 1.5$ & $1.1341 \pm 0.0011$ & $107303 \pm 223$ & $107042 \pm 289$ & $963 \pm 2$ & $106977 \pm 289$ \\
\hline DAT-7 & 171 & $187.0 \pm 0.2$ & $1051 \pm 21$ & $3255 \pm 66$ & $712 \pm 4$ & $1.1089 \pm 0.0037$ & $103615 \pm 671$ & $103531 \pm 673$ & $953 \pm 6$ & $103468 \pm 673$ \\
\hline DAT-20 & 154 & $204,3 \pm 0,2$ & $2749 \pm 55$ & $1339 \pm 27$ & $727.0 \pm 1.5$ & $1.0929 \pm 0.0011$ & $99868 \pm 215$ & $99668 \pm 257$ & $963 \pm 2$ & $99603 \pm 257$ \\
\hline DAT-21 & 125.7 & $159.7 \pm 0.1$ & $1709 \pm 34$ & $1673 \pm 34$ & $744.0 \pm 1.6$ & $1.0861 \pm 0.0011$ & $97373 \pm 206$ & $97215 \pm 234$ & $979 \pm 2$ & $97150 \pm 234$ \\
\hline DAT- 8 & 98.7 & $149.3 \pm 0.2$ & $759 \pm 15$ & $3593 \pm 73$ & $737 \pm 4$ & $1.1070 \pm 0.0039$ & $100847 \pm 664$ & $100772 \pm 666$ & $980 \pm 6$ & $100709 \pm 666$ \\
\hline DAT-22 & 56 & $196.9 \pm 0,1$ & $978 \pm 20$ & $3503 \pm 70$ & $694,6 \pm 1.5$ & $1.0554 \pm 0.0011$ & $97680 \pm 206$ & $97604 \pm 212$ & $915 \pm 2$ & $97539 \pm 212$ \\
\hline DAT-23 & 34 & $234.0 \pm 0.2$ & $359 \pm 7$ & $11228 \pm 226$ & $668.5 \pm 1,6$ & $1.0444 \pm 0.0013$ & $98598 \pm 236$ & $98574 \pm 237$ & $883 \pm 2$ & $98509 \pm 237$ \\
\hline DAT-9 & 15.2 & $240.4 \pm 0.2$ & $531 \pm 11$ & $7898 \pm 161$ & $677 \pm 3$ & $1.0581 \pm 0.0039$ & $99784 \pm 634$ & $99750 \pm 634$ & $897 \pm 4$ & $99687 \pm 634$ \\
\hline
\end{tabular}

$* \delta^{234} \mathrm{U}=\left(\left[{ }^{234} \mathrm{U} /{ }^{238} \mathrm{U}\right]\right.$ activity -1$) \times 1000$.

$* \delta^{234} \mathrm{U}_{\text {initial }}$ was calculated based on ${ }^{230} \mathrm{Th}$ age (T), i.e., $\delta^{234} \mathrm{U}_{\text {initial }}=\delta^{234} \mathrm{U}_{\text {measured }} \times e^{\lambda 234 \times T}$

** BP stands for "before present", where the "present" is defined as the year $1950 \mathrm{AD}$.

\section{Results}

\subsection{Speleothem morphology}

Figure 2c-e show the interpretation of the internal morphology of Han-9. In the lower part of the speleothem, below $365 \mathrm{~mm} \mathrm{dft}$, the calcite was well-laminated alternating between thick white and slightly darker layers. In the lower $15 \mathrm{~mm}$, some fine, brown detrital laminae can be seen, although they are confined to the very base and the lateral sides of the stalagmite. From $430 \mathrm{~mm}$ dft, the calcite becomes progressively coarser and layering less expressed with alternations between thicker parts of denser and coarser calcite. Starting from $365 \mathrm{~mm}$ dft, the speleothem calcite has a very coarse appearance and layering is almost indistinguishable. This goes on until $304 \mathrm{~mm} \mathrm{dft}$, where a first discontinuity in growth, D1, appears. This discontinuity was identified macroscopically. After D1, $100 \mathrm{~mm}$ of speleothem is characterized by alternating bands of dense and dark brown calcite with coarser, white calcite. Between 200 and $176 \mathrm{~mm} \mathrm{dft}$, a band of dense, brown calcite is present. Within this band, very fine laminae of red-brown material can be observed. This band ends with a second discontinuity, D2. Following D2, the axis of growth for the next $20 \mathrm{~mm}$ is tilted to the right. The entire upper section consists of dense and dark brown calcite, with little variation except for a coarser interval between 58 and $40 \mathrm{~mm} \mathrm{dft}$. Besides some subtle un- conformities marked by the dashed lines in Fig. 2d, no internal layering is visible macroscopically. Thin-section locations were chosen as representative of the typical morphologies displayed in the stratigraphic log in Fig. 2e. Fabrics are described according to Frisia (2015). In all thin sections, the dominant fabric of the calcite crystals was columnar (Fig. 3a). The layering, although often very well displayed macroscopically, was not distinguishable within the thin sections. Variations in fabric occur between macroscopically defined "denser" and "coarser" calcite (Fig. 2e), where the latter has smaller columnar calcite crystals with significantly more inter-crystalline porosity often filled with fluid inclusions (Fig. 3b) and is therefore described as columnar open. The denser morphology has substantially larger crystals with almost no pore space and can be defined as columnar elongated. Another type of fabric occurs within the dark brown band of dense calcite between 200 and $176 \mathrm{~mm} \mathrm{dft}$. There, the columnar fabric is replaced with smaller, more equant calcite crystals (Fig. 3c), which are then followed by a fine layer of brown detrital material representing D2.

\section{$4.2 \mathrm{U} /$ Th dating}

The results of $U / T h$ dating are shown in Table 1. Dating samples are labeled by "DAT-X", with X representing the sample number in Fig. 2d. All ages are displayed as "ka". In all samples, the detrital Th content, estimated by ${ }^{232} \mathrm{Th}$ concen- 

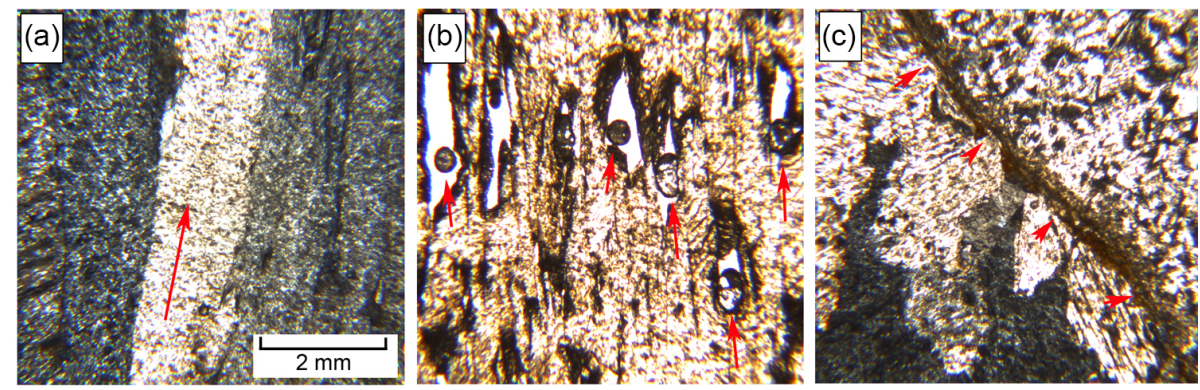

Figure 3. Thin section images of the Han-9. For locations, see Fig. 2d. All pictures are taken with crossed polarized light and have the same scale, and speleothem growth direction is upwards. (a) Thin section IIIB: (elongated) columnar calcite fabric. (b) IIIA: open columnar fabric, with fluid inclusions in the open voids. (c) IIA: discontinuity D2 is characterized by the presence of brown detrital material. Also note the different fabric underneath the hiatus.

tration and the initial ${ }^{230} \mathrm{Th} /{ }^{232} \mathrm{Th}$ atomic ratio, is relatively low (range: 6419-208 ppt). This leads to only minor corrections for the ${ }^{230} \mathrm{Th}$ age (Table 1). Errors are given as $2 \sigma$ and range between \pm 212 years and \pm 666 years. The $U$ and $T h$ concentrations determined in the 2013 samples allowed reduction of the sample size, resulting in smaller errors for the 2015 samples. From 672 to $176 \mathrm{~mm}$ dft, all ages are stratigraphically consistent; no age inversions occur when taking into account the $2 \sigma$ error of the U/Th ages. Between 176 and $0 \mathrm{~mm} \mathrm{dft}$, the distribution of the ages is more chaotic, with the occurrence of several age inversions and outliers.

\subsection{Stable isotopes: $\delta^{13} \mathrm{C}$ and $\delta^{18} \mathrm{O}$}

Figure $2 \mathrm{a}$ and $\mathrm{b}$ show the results of the $\delta^{13} \mathrm{C}$ and $\delta^{18} \mathrm{O}$ analyses, plotted against sample depth in $\mathrm{mm}$ dft. All values are expressed in \%o VPDB. The $\delta^{13} \mathrm{C}$ varies between -3.58 and $-10.30 \%$, with an average of $-7.53 \%$. The $\delta^{18} \mathrm{O}$ values show smaller variations, between -5.04 and $-7.02 \%$, with an average of $-5.91 \%$. Lower-amplitude variability in both $\delta^{13} \mathrm{C}$ and $\delta^{18} \mathrm{O}$ occurs in the lower part of the stalagmite, and larger-amplitude variations are present from $\sim 400 \mathrm{~mm} \mathrm{dft}$ upwards, corresponding with distinct transitions in morphology (alternating zones of dense, browner and coarser, whiter calcite; Fig. 2e).

\section{Discussion}

\subsection{Age model}

The StalAge algorithm (Scholz and Hoffmann, 2011) was applied to the individual ages in order to construct an agedepth model, displayed in Fig. 4. It is clear that the stalagmite endured three separate growth phases and that the discontinuities, expressed in the stalagmite morphology at 302 and $176 \mathrm{~mm}$ dft (Fig. 2d), correspond with two hiatuses separating these three growth phases. In the first growth phase, all ages are in stratigraphic order and are included within the model and the $2 \sigma$ error. DAT- 1 has only limited weight in the final model, and an explanation for this is given in

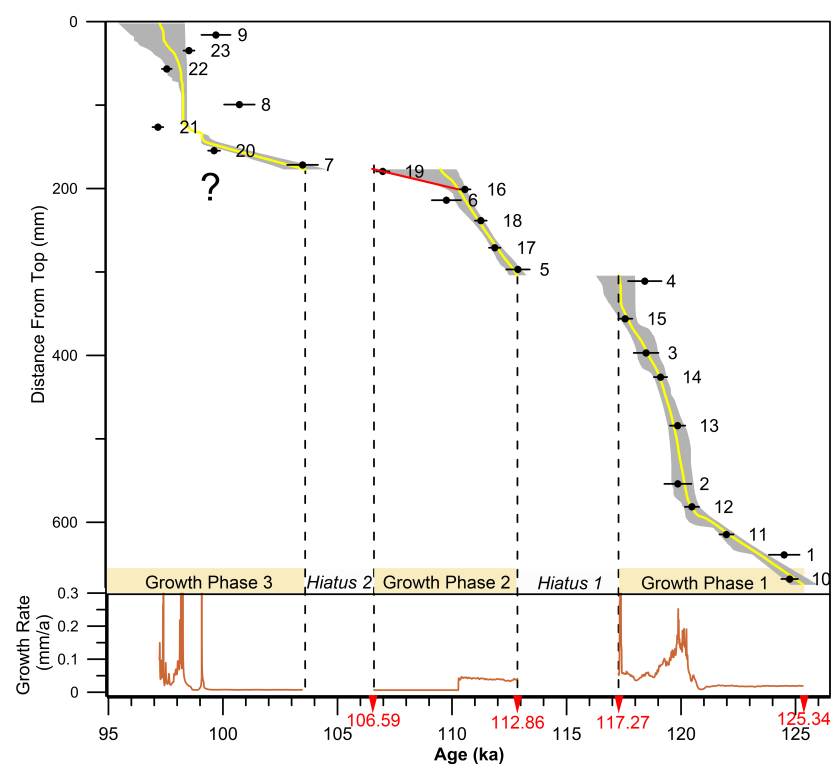

Figure 4. Han-9 age-depth model constructed with the StalAge algorithm (Scholz and Hoffmann, 2011). The actual age-depth model is represented by the yellow line; the grey area marks the error $(2 \sigma)$. Numbers represent the sample labels (Table 1). The brown curve displays the growth rate. Numbers in red indicate important dates and are discussed in the text.

the algorithm specifications (Scholz and Hoffmann, 2011). During the modeling process, the StalAge algorithm has a step where the data are screened for the occurrence of minor outliers and age inversions. This is done by fitting errorweighted straight lines through subsets of three adjacent data points. However, DAT-1 is located in the basal part of the stalagmite, so fewer subsets of three data points can be used including DAT-1. If DAT-1 does not fit on the error-weighted straight line created with the adjacent data points DAT-10 and DAT-11, which is the case here, then the error of DAT- 1 will be increased and the weight of DAT-1 in the Monte Carlo simulation for the age fitting will decrease. This results in fewer solutions where DAT- 1 is included in the Monte Carlo- 
simulated age models. The occurrence of substantial changes in growth rate in the boundary areas of a speleothem sample is recognized as a limitation of the StalAge algorithm (Scholz and Hoffmann, 2011). Even though the three growth phases were modeled separately with StalAge, the model does not perform well with the start of the Hiatus 2, as DAT-19 is completely excluded. Likely, this is again caused by the fact that DAT-19 is located in a boundary area. Here, the stalagmite petrography shows clear evidence of a significantly decreased growth rate after DAT-16 (110.6 ka), i.e., very dense, brownish calcite with fine laminae (Fig. $2 \mathrm{c}$ and e). In complex cases, such as in this study where multiple hiatuses occur, the simplest model is still the best. Therefore, linear interpolation combined with good observations of changes in petrography was applied to include DAT-19 within the age model (Fig. 4, red line). For the third growth phase, because of the occurrence of several age inversions, the resulting age model is unreliable. Despite the fact that ages clearly cluster between $\sim 103$ and $\sim 97 \mathrm{ka}$, the chronology of the third growth phase is only poorly constrained, and therefore a detailed interpretation of Han-9 in terms of paleoclimate is limited to the first two growth phases.

The first growth phase starts at $125.34+0.78 /-0.66 \mathrm{ka}$ with a stable growth rate of $0.02 \mathrm{~mm} \mathrm{yr}^{-1}$ up to around $120.5 \mathrm{ka}$. After that, the growth rate significantly increases, with values up to $0.15 \mathrm{~mm} \mathrm{yr}^{-1}$. At $117.27+0.69 /-1.02 \mathrm{ka}$, growth ceases and the first hiatus, $\mathrm{H} 1$, starts. The hiatus lasts $4.41+1.10 /-1.49 \mathrm{ka}$, and at $112.86+0.47 /-0.41 \mathrm{ka}$ growth phase 2 starts. DAT- 4 and DAT- 5 were taken $6 \mathrm{~mm}$ below and above the discontinuity, and the age-depth model does not show any reason to question the timing of $\mathrm{H} 1$. As for the second growth phase, growth rate remains at a constant pace of $0.04 \mathrm{~mm} \mathrm{yr}^{-1}$ until approximately $110.5 \mathrm{ka}$, where it decreases to $0.006 \mathrm{~mm} \mathrm{yr}^{-1}$. At $106.59+0.21 /-0.22 \mathrm{ka}$, the second growth phase ends. Given this age-depth model, stable isotopes were analyzed with a temporal resolution between 100 and 0.3 years, and an average of 16 years.

\subsection{Interpretation of stable isotope proxies}

\subsubsection{Isotopes deposited in isotopic equilibrium?}

The best test for the presence of kinetic fractionation is to have a reproducible record (Dorale and Liu, 2009). However, in the absence of a second stalagmite record, Hendy tests could be performed (Hendy, 1971). The problem here is that growth rates are rather low and the layering very fine, so it would be hard to sample precisely in one layer. Therefore, an additional test for correlation of $\delta^{13} \mathrm{C}$ and $\delta^{18} \mathrm{O}$ was done by calculating the Pearson's correlation coefficient on the entire record and on the three growth phases separately (Table 2). Yet a correlation between $\delta^{13} \mathrm{C}$ and $\delta^{18} \mathrm{O}$ does not give conclusive evidence for the presence of kinetic fractionation, as both $\delta^{13} \mathrm{C}$ and $\delta^{18} \mathrm{O}$ are expected to be controlled by climate and could therefore show positive or negative covaria-
Table 2. Pearson's coefficient of correlation $(\rho)$ calculated for the three growth phases and for the total record.

\begin{tabular}{lrr}
\hline & $\rho$ & No. of measurements \\
\hline Growth phase 1 & 0.024 & 599 \\
Growth phase 2 & -0.467 & 235 \\
Growth phase 3 & 0.461 & 284 \\
Total & -0.197 & 1118 \\
\hline
\end{tabular}

tion (Dorale and Liu, 2009). The Pearson's coefficients reveal that there is a clear difference between the separate growth phases. The first growth phase, with $\rho=0.024$, marks no covariation. The second growth phase, with $\rho=-0.467$, has a substantial degree of negative covariation, whereas the third growth phase $(\rho=0.461)$ has a positive covariation. The differences between the coefficients of the separate growth phases indicate that several processes are controlling the stable isotope variability and that the presence or absence of covariation reflects changes in climate conditions between the growth phases rather than the presence or absence of equilibrium. Nevertheless, equilibrium deposition between the drip water and recent calcite in the Han-sur-Lesse Cave has been observed by Van Rampelbergh et al. (2014).

\subsubsection{Variations in speleothem $\delta^{13} \mathrm{C}$}

The $\delta^{13} \mathrm{C}$ in Han-9 is controlled by changes in vegetation assembly above the cave. This is deduced from the match between Han-9 $\delta^{13} \mathrm{C}$ and the abundance of grass pollen in the assembly of Sirocko et al. (2005) recovered from the Eifel Maar (Fig. 1a and Fig. 5). The agreement between Han-9 $\delta^{13} \mathrm{C}$ and the Eifel pollen assembly is remarkable; increases in $\delta^{13} \mathrm{C}$ occur when the percentage of grass pollen increases in the Eifel record. Similar shifts in grass/forest vegetation have even been observed the Vosges region, France, $300 \mathrm{~km}$ further south (Woillard, 1978; de Beaulieu and Reille, 1992; de Beaulieu, 2010) and in other records from northern and central Europe (Helmens, 2014, and references therein). Also, the $\delta^{13} \mathrm{C}$ of recent calcite formed with a current foresttype vegetation above the cave is $\sim-8 \%$ o (Table 3 ). These values are similar to those observed during the last interglacial in Han-9 (125.3-117.3 ka, Fig. 5). Changes in $\delta^{13} \mathrm{C}$ of several per mill are often attributed to changes in $\mathrm{C} 3$ versus C4 plants (McDermott, 2004). However, a higher abundance of grasses does not necessarily result in an increased amount of $\mathrm{C} 4$ vegetation. First of all, $\mathrm{C} 4$ species only make up $\sim 1 \%$ of the total amount of vascular plant species in northwestern Europe today (Pyankov et al., 2010). Secondly, C4 species dominantly occur in a warmer, tropical climate (Ehleringer et al., 1997). Finally, within the subfamily of the Pooideae, commonly referred to as the cool-season grasses and thriving in temperate European climate, all species use the C3 pathway (Soreng et al., 2015). The reason why speleothem calcite tends to be enriched in ${ }^{13} \mathrm{C}$ when vegetation is dominated by 
Table 3. $\delta^{13} \mathrm{C}$ and $\delta^{18} \mathrm{O}$ analysis of three recent calcite samples (RC1 to RC3) from the Réseau Renversé.

\begin{tabular}{rrr}
\hline & $\delta^{13} \mathrm{C}$ & ${ }^{18} \mathrm{O}$ \\
\hline $\mathrm{RC} 1$ & -8.19 & -5.73 \\
$\mathrm{RC} 2$ & -8.20 & -6.25 \\
$\mathrm{RC} 3$ & -7.80 & -6.48 \\
\hline
\end{tabular}

grasses is because grasses have a smaller biomass than trees and also the amount of soil respiration is lower, both leading to a smaller fraction of biogenic $\mathrm{CO}_{2}$ compared to (heavier) atmospheric $\mathrm{CO}_{2}$ within the soil (Genty et al., 2003). The similarity between the two records does not seem to hold up after $109 \mathrm{ka}$. From here on, $\delta^{13} \mathrm{C}$ becomes more depleted while the Eifel record shifts towards an assembly dominated by grasses. It is not clear what might have caused this depletion, but since growth rates are very low after 109 ka (Fig. 4), it could be related to prior calcite precipitation (PCP). PCP is known to act as a control mechanism on seasonal variations in $\delta^{13} \mathrm{C}$ of Han-sur-Lesse speleothems, as concluded from an elaborate cave-monitoring study by Van Rampelbergh et al. (2014). However, the study by Van Rampelbergh et al. (2014) was carried out on a large, tabular-shaped stalagmite with drip water discharge rates of $300 \mathrm{~mL} \mathrm{~min}^{-1}$ and growth rates of $\sim 1 \mathrm{~mm} \mathrm{yr}^{-1}$, so caution is required when extrapolating these cave-monitoring conclusions to smaller, slower-growing stalagmites in a different part of the cave system. If PCP occurs at one site in the cave, it does not mean that it occurs over the entire cave (Riechelmann et al., 2011). Since no additional data on $\mathrm{Sr}$ and $\mathrm{Mg}$ are currently available for Han-9, the presence of PCP can be neither confirmed nor rejected.

To summarize, the control on Han- $9 \delta^{13} \mathrm{C}$ variations is the amount of biogenic $\mathrm{CO}_{2}$ in the soil, caused by changes in the vegetation type above the cave (forest/grasses), which is directly linked to climate. Lower, depleted $\delta^{13} \mathrm{C}$ values occur during warmer and wetter periods, when vegetation is dominated by temperate trees. Higher, enriched $\delta^{13} \mathrm{C}$ values of speleothem calcite correspond with a higher abundance of grasses above the cave during colder/dryer climate intervals.

\subsubsection{Variations in speleothem $\delta^{18} \mathrm{O}$}

In midlatitude Europe, several different processes (including temperature, amount effect and ocean source) influence speleothem $\delta^{18} \mathrm{O}$ variability (McDermott, 2004). A good overview of all processes possibly influencing the speleothem $\delta^{18} \mathrm{O}$ is given by Lachniet (2009). One of the main processes acting on both precipitation $\delta^{18} \mathrm{O}$ and calcite $\delta^{18} \mathrm{O}$ is temperature. Temperature fractionation on vapor condensation was estimated to be around $0.6 \% 0^{\circ} \mathrm{C}^{-1}$ (Rozanski et al., 1992), and the temperature-dependent fractionation between cave drip water and speleothem calcite for

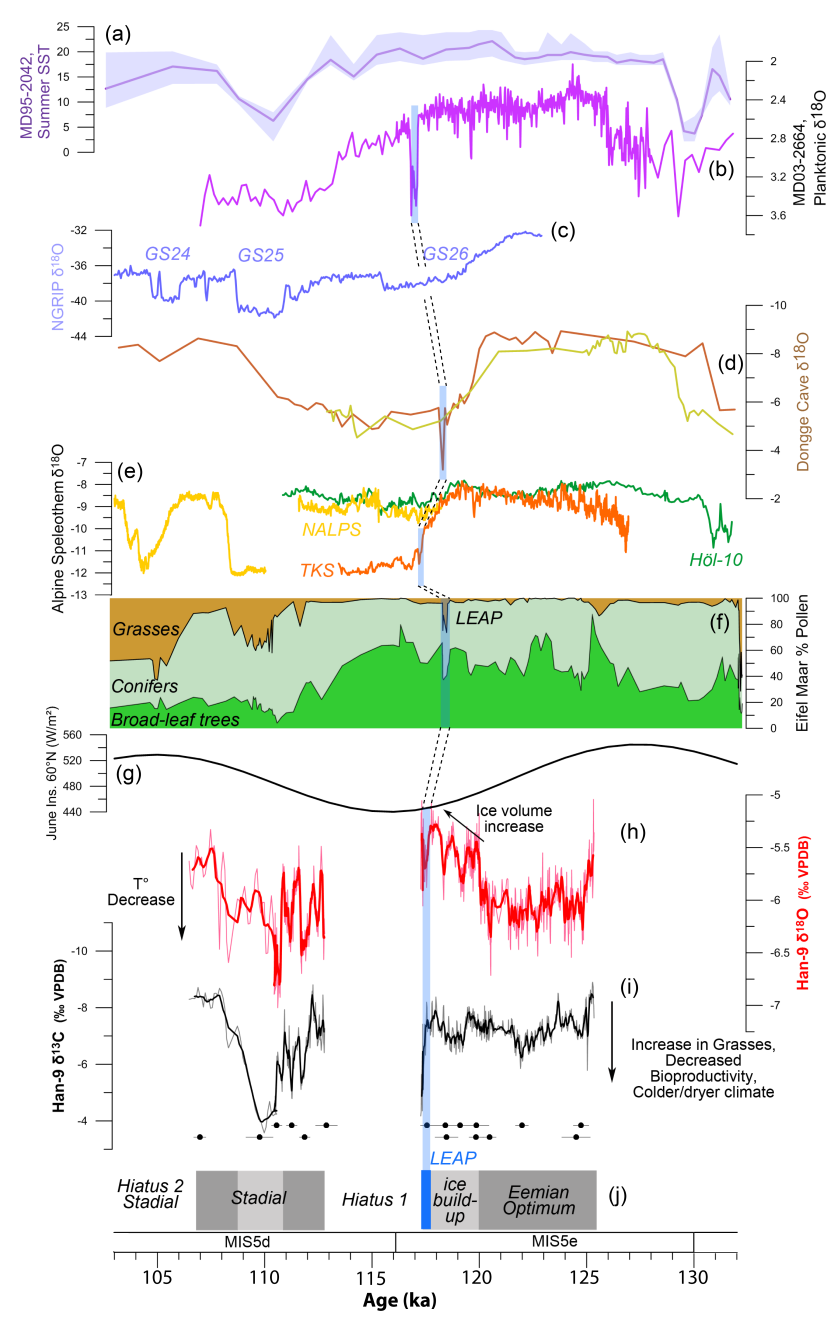

Figure 5. Comparison of Han-9 stalagmite with other records. The shaded blue area marks the occurrence of the late Eemian aridity pulse (LEAP) in the Eifel record and its equivalent in other records. (a) Sea surface temperature (SST) reconstruction from marine core MD04-2845 (Sanchez-Goñi et al., 2012); (b) planktonic $\delta^{18} \mathrm{O}$ from marine core MD03-2664 (Irvali et al., 2012); (c) NGRIP $\delta^{18} \mathrm{O}$ record with indication of Greenland stadial intervals (NGRIP members, 2004); (d) Asian monsoon reconstructions from Dongge Cave (D3 \& D4 stalagmites; Yuan et al., 2004); (e) Alpine speleothem $\delta^{18} \mathrm{O}$ (TKS: Meyer et al., 2008; NALPS: Boch et al., 2011; HöL10: Moseley et al., 2015); (f) Eifel Maar pollen assembly (Sirocko et al., 2005); (g) June insolation for $60^{\circ} \mathrm{N}$ (Berger and Loutre, 1991); (h, i) Han-9 stable isotope record with a seven-point moving average and U/Th dates; (j) paleoclimate interpretation of Han-9.

the Han-sur-Lesse Cave was calculated to be $-0.2 \%{ }^{\circ} \mathrm{C}^{-1}$ (Van Rampelbergh et al., 2014). The eventual relation between temperature and speleothem $\delta^{18} \mathrm{O}$ will be positive; lower temperatures will thus lead to more negative speleothem $\delta^{18} \mathrm{O}$. The temperature control has been attributed as one of the main drivers of $\delta^{18} \mathrm{O}$ fluctuations in European speleothems (Boch et al., 2011; Wainer et al., 
2013). In Han-9, this temperature control is well expressed in growth phase 2 , where more positive $\delta^{13} \mathrm{C}$ values, which reflect lower temperatures through changes in vegetation, correspond with more negative $\delta^{18} \mathrm{O}$ (Fig. 5). This also explains the negative covariation as shown by the Pearson's correlation coefficient for growth phase 2 (Table 2). It is very likely that in this record the amount of precipitation also partly influences the $\delta^{18} \mathrm{O}$ signal of the speleothem. In the tropics, variations in monsoonal strength are regarded as the main control on speleothem $\delta^{18} \mathrm{O}$ via the amount effect (Wang et al., 2001), and changes in the amount of precipitation over time have also been considered as a driver for variations within European speleothem $\delta^{18} \mathrm{O}$ records (Genty et al., 2003; Couchoud et al., 2009, McDermott et al., 2011). Temperature and precipitation (through the amount effect) controls are thus expected to contribute most to the speleothem $\delta^{18} \mathrm{O}$ variability, but as this record covers an interglacialglacial transition, other processes acting on longer timescales (i.e., fluctuations in global ice volume) should also be considered. A significant contribution is to be expected from the variations in $\delta^{18} \mathrm{O}$ of the source, i.e., the North Atlantic Ocean, because of fluctuations in global ice volume. Waelbroeck et al. (2002) estimated that, during MIS 5d, average global $\delta^{18} \mathrm{O}$ values of ocean waters were up to $0.5 \%$ higher compared to MIS 5e.

\subsection{Climate in the Belgian area between 125.3 and $\sim 97 \mathrm{ka}$}

\subsubsection{3 ka: start of speleothem growth triggered by an increase in moisture availability}

The age model implies that Han-9 started growing at $125.3 \mathrm{ka}$ (Fig. 4). Among the recent sampling missions for Belgian LIG speleothems, this is the oldest LIG sample found so far (S. Verheyden, personal communication, 2015). Although a flowstone from the same Han-sur-Lesse Cave was reported to start growing at $130 \pm 10 \mathrm{ka}$ (Quinif and Bastin, 1994), the accuracy of that one single alpha spectrometric dating result can be questioned. Cave systems in Belgium are known to be very sensitive recorders of glacial-interglacial changes, with speleothem deposition only during interglacial intervals (Quinif, 2006). Between 131.5 and $126.5 \mathrm{ka}$, the Greenland Ice Sheet experienced enhanced deglacial melting, and reinforced AMOC conditions were also present, as identified from the MD04-2845 core from the Bay of Biscay (Sánchez Goñi et al., 2012). Speleothem formation, however, did occur in the Alps and in southern Europe before $125.3 \mathrm{ka}$ (Moseley et al., 2015; Drysdale et al., 2009). This raises the question whether or not the start of Han-9 growth is just sample specific or if it represents a real, albeit maybe locally confined, climate event at $125.3 \mathrm{ka}$. The SCH-5 Alpine speleothem (Fig. 1a) was continuously deposited between $134.1 \pm 0.7$ and $115.3 \pm 0.6 \mathrm{ka}$ (Moseley et al., 2015). Within this record, an increase in the $\delta^{18} \mathrm{O}$ proxy starting at $128.4 \mathrm{ka}$ and lasting to $125.3 \mathrm{ka}$ was identified as a warming phase. The warming phase recognized in this Alpine speleothem occurs just prior to the start of the Han9 speleothem growth, emphasizing a possible link between the warming and the start of speleothem formation in Hansur-Lesse. In the BDInf speleothem from southern France (Couchoud et al., 2009) (Fig. 1a), the interval between 125.3 and $123.8 \mathrm{ka}$ was identified as a period with increased rainfall amount. A warmer/wetter period is potentially expressed in northwest European vegetation records as well, such as the Eifel Maar record (Sirocko et al., 2005), located only $150 \mathrm{~km}$ from the cave site in this study. At $125 \mathrm{ka}$, a transition of a pollen assembly consisting mainly of pioneering Betula pollen with boreal Pinus towards an assembly significantly richer in thermophilous, broadleaf tree pollen such as Ulmus, Quercus, Corylus and Carpinus is observed. However, the chronology of this record was not constructed independently; the start of the Eemian was determined by cross-correlating with the U/Th dates of the SPA-50 Alpine speleothem record of Holzkämper et al. (2004) and set at $127 \mathrm{ka}$. The Han-9 $\delta^{13} \mathrm{C}$ record at $125.3 \mathrm{ka}$ has the most negative values for the entire 125.3-117.3 ka growth period, reaching almost $-9 \%$. $\delta^{18} \mathrm{O}$ on the other hand registers a decrease $>0.5 \%$ during the first 300 years of growth (Fig. 5). The low $\delta^{13} \mathrm{C}$ values perhaps demonstrate that interglacial optimum conditions were already present before $125.3 \mathrm{ka}$ but that an increase in moisture availability caused by enhanced precipitation above the cave, shown by the $\delta^{18} \mathrm{O}$ decrease, was the factor needed to trigger growth of Han-9.

\subsubsection{5-120 ka: Eemian optimum}

The isotope records of Han-9 are relatively stable between 125 and $\sim 120 \mathrm{ka}$ (Fig. 5). The variation of $\delta^{18} \mathrm{O}$ seems to be submillennial and is largely confined to between -5.7 and $-6.3 \%$. The long-term trend, as displayed by a fitted seven-point running average (Fig. 5), shows lower variability between 125 and $\sim 120 \mathrm{ka}$, especially when compared to younger growth periods of Han-9 (i.e., 120-117.3 and 112.9$106.6 \mathrm{ka})$. Similar observations are made for $\delta^{13} \mathrm{C}$ : submillennial variability is restricted between -7 and $-8 \%$, with the exception of a positive excursion towards $-6 \%$ around $122 \mathrm{ka}$, and generally more stable than in younger time intervals. During 125-120 ka, other paleoclimate records display stable interglacial conditions, such as speleothems from the Alps (Meyer et al., 2008; Moseley et al., 2015) and from Italy (Drysdale et al., 2009), and other archives including ice cores (NEEM community, 2013) (Fig. 5). In marine records off the Iberian Margin, the 125-119 ka period was identified as an interval of "sustained European warmth", following a time of enhanced Greenland melting between 131.5 and $126.5 \mathrm{ka}$ (Sánchez Goñi et al., 2012). We therefore attribute the stability of our records to the Eemian climate optimum persisting in the Belgian area as well. This is also supported by the constant growth rate (Fig. 4) and the speleothem mor- 
phology, displaying a sequence of layered calcite which does not show any significant change over the $125-120 \mathrm{ka}$ period (Fig. 2c-e).

\subsubsection{0-117.3 ka: inception of glacial conditions}

At $120 \mathrm{ka}$, an increase in $\delta^{18} \mathrm{O}$ of $0.5 \%$ is observed (Fig. 5). This change in $\delta^{18} \mathrm{O}$ of the speleothem corresponds with an elevated growth rate (Fig. 4) and a speleothem morphology that becomes progressively coarser, with layers that are less expressed (Fig. 2c and e). No major changes in the $\delta^{13} \mathrm{C}$ are observed. Although both the age-depth model and the speleothem morphology support an increase in speleothem growth rate, possibly in response to an increase in moisture availability within the cave, there is no evidence in the Han$9 \delta^{18} \mathrm{O}$ record for an increase in precipitation. Due to the amount effect, enhanced precipitation would cause the $\delta^{18} \mathrm{O}$ signal to shift towards more negative values, which is not observed in the record. The increase in growth rate, along with the accompanying faster $\mathrm{CO}_{2}$ degassing during speleothem formation, is known to act as a possible kinetic control on the speleothem $\delta^{18} \mathrm{O}$ (Hendy, 1971; Lachniet, 2009), yet kinetic control by fast degassing would also result in positive changes of $\delta^{13} \mathrm{C}$ (Baker et al., 1997), which is not the case here. Another possible explanation could be a temperature rise causing the elevated $\delta^{18} \mathrm{O}$ signal, although such locally confined temperature increase seems unlikely, because no other records (pollen, sea surface temperature) support this hypothesis. Most likely, this increase in $\delta^{18} \mathrm{O}$ is not related to any local climate effects but reflects a more regional signal, which could be the increase of the source $\delta^{18} \mathrm{O}$ of the North Atlantic Ocean, since a rise of $0.5 \%$ is in good agreement with estimations of the source $\delta^{18} \mathrm{O}$ variability over the MIS $5 \mathrm{e}-5 \mathrm{~d}$ transition from Waelbroeck et al. (2002). As a matter of fact, a study by Hearty et al. (2007) combining last interglacial sea-level evolution at 15 sites around the world shows a rapid descent towards an MIS 5d low stand at $119 \pm 2 \mathrm{ka}$. This also favors the hypothesis that the speleothem $\delta^{18} \mathrm{O}$ between 120 and $117.3 \mathrm{ka}$ reflects changing ocean source due to ice buildup.

A severe change in the $\delta^{13} \mathrm{C}$ is not observed until $117.5 \mathrm{ka}$, where a sudden increase towards $-4 \%$ occurs (Fig. 5). This $5 \%$ o change takes place within 200 years and happens just before the first hiatus in this speleothem, suggesting that the cessation in speleothem growth is indeed caused by a climate event. The increase in $\delta^{13} \mathrm{C}$ here is believed to reflect changes in vegetation, such as an increase in grasses resulting in lower vegetation activity, linked to a changing (drying and/or cooling) climate. The age of this event, $117.3 \mathrm{ka}$, stands out in other studies as well. First of all, in the NGRIP $\delta^{18} \mathrm{O}$ record it falls within what is identified as Greenland Stadial 26 (NGRIP Members, 2004). Although the signature of this GS may not be as clear as the younger GS 25 or 24 , it corresponds with the overall decreasing trend observed in the ice $\delta^{18} \mathrm{O}$ and is also recognized in the more recent NEEM ice core (NEEM community, 2013). The global character of this climate event around $117.3 \mathrm{ka}$ is evidenced by similar changes in the North Atlantic Ocean. A high-resolution study by Galaasen et al. (2014) has found perturbations of the $\delta^{13} \mathrm{C}$ of benthic foraminifera in marine sediment cores, interpreted as a sharp decrease in North Atlantic Deep Water (NADW) formation at $116.8 \mathrm{ka}$, in contrast with the high NADW formation observed during MIS 5e. Such reductions in NADW led to changes in AMOC, resulting in a reduced ocean heat transport and eventually cooling of the climate. This hypothesis is further evidenced by lower sea surface temperatures, shown by an increase in planktonic foram $\delta^{18} \mathrm{O}$, in marine core MD03-2664 at that time (Irvali et al., 2012) (Fig. 5). The lower resolution in the sea surface temperature record of core MD04-2548 retrieved from the Bay of Biscay (Fig. 1a) could explain its absence in this archive (Fig. 5). Other accurately dated European speleothem records mark a similar climate deterioration around the same time. Perhaps the most obvious example is the study from Meyer et al. (2008), where a 3 to $4 \%$ drop in $\delta^{18} \mathrm{O}$ of four different flowstones from the Entrische Kirche Cave (Fig. 1a) is observed between 119 and $118 \mathrm{ka}$ (Fig. 5). This large drop in speleothem $\delta^{18} \mathrm{O}$ is believed to be caused by a severe cooling and was defined as the glacial inception at the cave site. Furthermore, a subtle depletion occurs in the HÖL-10 stalagmite (Fig. 5) and was correlated to the $\delta^{18} \mathrm{O}$ drop from Entrische Kirche (Moseley et al., 2015). Closer to the Han-sur-Lesse Cave, a similar event was also observed in the Eifel Maar record. There it was identified as the "LEAP", or the late Eemian aridity pulse, and defined by an increase in varve thickness, loess and charcoal content together with a higher abundance of grass pollen within the assembly (Sirocko et al., 2005), which would explain the increase in $\delta^{13} \mathrm{C}$ of Han-9. Yet, the timing of the LEAP predates the Han-9 event by $\sim 1 \mathrm{ka}$. Nevertheless, we suggest that both records registered the same event and that the offset in chronology can be caused by the tuning of the Eifel record or the uncertainty of the Han-9 age-depth model at $117.3 \mathrm{ka}$.

\subsubsection{3-97 ka: stadial-interstadial changes in the early Weichselian}

After the first hiatus, growth starts again at $112.9 \mathrm{ka}$. The LEAP event in the Eifel Maar only lasts 468 years (Sirocko et al., 2005), yet speleothem growth does not recover immediately after the LEAP event. A similar observation was made for the start of speleothem growth at $125.3 \mathrm{ka}$ : optimum conditions were already present before Han-9 started growing. From this delayed growth, it appears that climate conditions need to be more favorable (warmer/wetter) to initiate growth than to sustain growth. During the second growth phase of the Han-9 stalagmite (112.9-106.6 ka), interesting differences occur compared to the earlier-formed part of the speleothem. First of all, the variation of both $\delta^{18} \mathrm{O}$ and $\delta^{13} \mathrm{C}$ is much larger (Fig. 5). Secondly, changes in stalagmite morphology appear, with alternations between dense, darker cal- 
cite and whiter, coarser calcite (Fig. $2 \mathrm{c}-\mathrm{e}$ ). The $\delta^{13} \mathrm{C}$ curve of Han-9 shows a long-term increasing trend until a maximum of $-4 \%$ is reached at $110 \mathrm{ka}$. Superimposed on this trend, (sub)millennial variability ranging between 2 and $3 \%$ o is present. In contrast, within the $\delta^{18} \mathrm{O}$ record a long-term trend is not as obvious, although a minimum of $-6.8 \%$ is reached between 111 and $110 \mathrm{ka}$. The maximum in $\delta^{13} \mathrm{C}$ and the minimum in $\delta^{18} \mathrm{O}$ correspond well with the timing of GS 25 (110.6-108.3 ka; Rasmussen et al., 2014) observed in the NGRIP record (plotted on the GICC05modelext timescale), implying that the stable isotopes of Han-9 reflect the temperature decrease of the stadial, which is likely since higher $\delta^{13} \mathrm{C}$ is linked to a less active vegetation cover during colder periods (i.e., more grasses) and lower $\delta^{18} \mathrm{O}$ is caused by lower temperatures. The timing in the Han-9 record is also in agreement with the GS 25 registered in the NALPS record, which is believed to be dominantly temperature dependent (Boch et al., 2011). The summer sea surface temperature reconstructions for marine core MD04-2845 show a distinct decrease of $\sim 10^{\circ} \mathrm{C}$ at the same time (Sánchez Goñi et al., 2012). Between 112.9 and $111 \mathrm{ka}$, the variability of $\delta^{13} \mathrm{C}$ and $\delta^{18} \mathrm{O}$ in Han-9, predating GS 25, has an inverse relationship suggesting that $\delta^{18} \mathrm{O}$ is mainly temperature controlled. The ice buildup effect, displayed by the increase in $\delta^{18} \mathrm{O}$ between 120 and $117.3 \mathrm{ka}$, is cancelled out by the effect of lower temperature, causing a decrease in speleothem $\delta^{18} \mathrm{O}$. It also appears that, for a general cooler climate state, the amplitude of variability tends to increase as well, compared to a more stable Eemian optimum (125-120 ka). The timing of the second hiatus $(106.6-103 \mathrm{ka})$ is similar to that of the occurrence of GS 24 in the NGRIP record and is also registered in the NALPS dataset from Boch et al. (2011). However, if the hiatus has any affinity with GS 24 , this raises the question why speleothem growth stopped during GS 24 and continued during GS 25. A plausible explanation could be that growth never fully recovered from the GS 25 , and that less favorable conditions (cooler/dryer) during the GS 24 interval were sufficient to cease growth. This assumption is grounded by decreased growth rate from 110 ka onwards (Fig. 4). In the Eifel Maar core, significant changes in vegetation occur from $\sim 112 \mathrm{ka}$, with nearly all pollen from broadleaf trees disappearing and the transition towards a pollen assembly dominated by coniferous trees and grasses (Fig. 5). Also, the time periods $110-108.5 \mathrm{ka}$ and $106-104.5 \mathrm{ka}$ are characterized by a significant increase in loess composition and varve thickness, indicative for dryer conditions in that area and corresponding with the GS 25 and GS 24 intervals (Sirocko et al., 2005).

\section{Conclusions}

This study highlights the potential of Belgian speleothem proxies (i.e., growth, morphology and stable isotopes) as recorders of regional and local climate change over the
Eemian and early Weichselian in northwestern Europe. The start of speleothem growth occurs at $125.3 \mathrm{ka}$. At that time, however, nearly all of the European continental records are already within the Eemian climate optimum state. The $\delta^{18} \mathrm{O}$ record suggests that the eventual trigger starting speleothem growth was most likely moisture availability, linked to an increase in (local) precipitation at that time. Optimum Eemian climate conditions recorded in Han-9 occurred between 125.3 and $120 \mathrm{ka}$, and the stable isotopes and speleothem morphology indicate a relatively stable climate state. The first signs of regional changing climate are observed in the $\delta^{18} \mathrm{O}$ proxy from $120 \mathrm{ka}$ onwards and are linked to a changing ocean source $\delta^{18} \mathrm{O}$, caused by increasing ice volume. The end of the Eemian (and start of the early Weichselian) in Han-9, at $117.3 \mathrm{ka}$, is preceded by a drastic change in vegetation activity and/or assembly that took place within 200 years, triggered by a decrease in moisture availability linked to a drying climate. This eventually led to cessation of speleothem growth. This event appears to have a broad regional signature, as it is registered in other European records as well. However, pollen records imply that temperate vegetation seems to persist several millennia after $117.3 \mathrm{ka}$ (de Beaulieu and Reille, 1992; Sirocko et al., 2005), resulting in a longer duration of the Eemian in other records (Tzedakis et al., 2003). In addition, Han-9 also registered three stadials occurring during the early Weichselian. During GS 26, at $117.3 \mathrm{ka}$, the end of the Eemian in Han-9 occurs. The GS 25 equivalent occurs between 110.5 and $108.5 \mathrm{ka}$ as deduced from the stable isotope proxies, and GS 24 is represented by a hiatus in Han-9 that starts at 106.6 ka. These chronologies are consistent with other European speleothem records. For the early Weichselian, local climate appears to be more sensitive during the early glacial conditions as the amplitude and frequency of isotopic shifts tend to increase significantly compared to the Eemian.

\section{Data availability}

Stable isotope time series for the first two growth phases are available online at NOAA paleoclimate database.

Acknowledgements. We thank the Domaine des Grottes de Han for allowing us to sample the stalagmite and to carry out other fieldwork. S. Vansteenberge thanks D. Verstraeten for the assistance with the stable isotope measurements. P. Claeys thanks the Hercules Foundation for the upgrade of the Stable Isotope Laboratory at VUB and the VUB Strategic Research funding.

Edited by: A. Dutton 


\section{References}

Baker, A., Ito, E., Smart, P. L., and McEwan, R. F.: Elevated and variable values of $\mathrm{C}-13$ in speleothems in a British cave system, Chemical Geology, 136, 263-270, 10.1016/s00092541(96)00129-5, 1997.

Bar-Matthews, M., Ayalon, A., Kaufman, A., and Wasserburg, G. J.: The Eastern Mediterranean paleoclimate as a reflection of regional events: Soreq cave, Israel, Earth Planet. Sci. Lett., 166, 85-95, doi:10.1016/S0012-821X(98)00275-1, 1999.

Barker, S., Chen, J., Gong, X., Jonkers, L., Knorr, G., and Thornalley, D.: Icebergs not the trigger for North Atlantic cold events, Nature, 520, 333-336, 2015.

Bastin, B. and Gewelt, M.: Analyse pollinique et datation 14C de concrétions stalagmitiques Holocènes: apportes complémentaires des deux méthodes, Géographie Physique et Quaternaire, 40, 185-196, 1986.

Berger, A. and Loutre, M. F.: An Exceptionally Long Interglacial Ahead?, Science, 297, 1287-1288, doi:10.1126/science.1076120, 2002.

Boch, R., Cheng, H., Spötl, C., Edwards, R. L., Wang, X., and Häuselmann, Ph.: NALPS: a precisely dated European climate record 120-60 ka, Clim. Past, 7, 1247-1259, doi:10.5194/cp-71247-2011, 2011.

Bond, G., Broecker, W., Johnsen, S., McManus, J., Labeyrie, L., Jouzel, J., and Bonani, G.: Correlations between climate records from North-Atlantic sediments and Greenlan Ice, Nature, 365, 143-147, doi:10.1038/365143a0, 1993.

Bond, G. C.: Climate and the conveyor, Nature, 377, 383-384, 1995.

Bonniver, I.: Hydrogéologie du Massif de Boine, in: EcoKarst, 3, La Hulpe, 1-4, 2010.

Bonniver, I.: Etude Hyrogeologique et dimmensionnement par modelisation du "systeme-tracage" du reseau karstique the Hansur-Lesse (Massif de Boine, Belgique), in: Géologie, FUNDP Namur, Namur, 93-97, 2011.

Broecker, W. S., Peteet, D. M., and Rind, D.: Does the oceanatmosphere system have more than one stable mode of operation?, Nature, 315, 21-26, 1985.

Couchoud, I., Genty, D., Hoffmann, D., Drysdale, R., and Blamart, D.: Millennial-scale climate variability during the Last Interglacial recorded in a speleothem from southwestern France, Quaternary Sci. Rev., 28, 3263-3274, doi:10.1016/j.quascirev.2009.08.014, 2009.

Cheng, H., Edwards, R. L., Chuan-Chou, S., Polyak, V. J., Asmerom, Y., Woodhead, J., Hellstrom, J., Yongjin, W., Xinggong, K., Spotl, C., Xianfeng, W., and Alexander Jr., E. C.: Improvements in 230Th dating, 230Th and 234U half-life values, and UTh isotopic measurements by multi-collector inductively coupled plasma mass spectrometry, Earth Planet. Sci. Lett., 371-372, 8291, doi:10.1016/j.eps1.2013.04.006, 2013.

Dansgaard, W., Johnsen, S. J., Clausen, H. B., Dahl-Jensen, D., Gundestrup, N. S., Hammer, C. U., Hvidberg, C. S., Steffensen, J. P., Sveinbjornsdottir, A. E., Jouzel, J., and Bond, G.: Evidence for general instability of past climate from a $250-\mathrm{kyr}$ ice-core record, Nature, 364, 218-220, 1993.

de Beaulieu, J.-L. (Ed.): Pollen Profile GPILXX, La Grande Pile, France, de Beaulieu, J.-L., Pangaea, European Pollen Database, 2010. de Beaulieu, J. L. and Reille, M.: The last climatic cycle at La Grande Pile (Vosges, France) a new pollen profile, Quaternary Sci. Rev., 11, 431-438, doi:10.1016/0277-3791(92)900254, 1992.

Dorale, J. A. and Liu, Z.: Limitations of Hendy test criteria in judging the paleoclimatic suitability of speleothems and the need for replication, J. Cave Karst Stud., 71, 73-80, 2009.

Drysdale, R. N., Zanchetta, G., Hellstrom, J. C., Fallick, A. E., McDonald, J., and Cartwright, I.: Stalagmite evidence for the precise timing of North Atlantic cold events during the early last glacial, Geology, 35, 77-80, 2007.

Drysdale, R. N., Hellstrom, J. C., Zanchetta, G., Fallick, A. E., Sánchez Goñi, M. F., Couchoud, I., McDonald, J., Maas, R., Lohmann, G., and Isola, I.: Evidence for Obliquity Forcing of Glacial Termination II, Science, 325, 1527-1531, 2009.

Dutton, A. and Lambeck, K.: Ice Volume and Sea Level During the Last Interglacial, Science, 337, 216-219, doi:10.1126/science.1205749, 2012.

Edwards, R. L., Chen, J. H., Ku, T. L., and Wasserburg, G. J.: Precise Timing of the Last Interglacial Period from Mass Spectrometric Determination of Thorium-230 in Corals, Science, 236, 1547-1553, 1987.

Ehleringer, J. E., Cerling, T. E., and Helliker, B. R.: C4 photoynthesis, atmospheric $\mathrm{CO}_{2}$, and climate, Oecologia, 112, 285-299, 1997.

Fairchild, I. and Baker, A.: Speleothem Science: from Process to Past Environments, Wiley-Blackwell, 2012.

Fairchild, I. J., Smith, C. L., Baker, A., Fuller, L., Spotl, C., Mattey, D., McDermott, F., and Eimp: Modification and preservation of environmental signals in speleothems, Earth-Sci. Rev., 75, 105153, doi:10.1016/j.earscirev.2005.08.003, 2006.

Friedman, I., O’Neil, J., and Cebula, G.: Two New Carbonate Stable-Isotope Standards, Geostandards Newsletter, 6, 11-12, doi:10.1111/j.1751-908X.1982.tb00340.x, 1982.

Frisia, S.: Microstratigraphic logging of calcite fabrics in speleothems as tool for palaeoclimate studies, Int. J. Speleol., 44, 1-16, doi:10.5038/1827-806x.44.1.1, 2015.

Galaasen, E. V., Ninnemann, U. S., Irvali, N., Kleiven, H. F., Rosenthal, Y., Kissel, C., and Hodell, D. A.: Rapid Reductions in North Atlantic Deep Water During the Peak of the Last Interglacial Period, Science, 343, 1129-1132, doi:10.1126/science.1248667, 2014.

Genty, D., Blamart, D., Ouahdi, R., Gilmour, M., Baker, A., Jouzel, J., and Van-Exter, S.: Precise dating of Dansgaard-Oeschger climate oscillations in western Europe from stalagmite data, Nature, 421, 833-837, 2003.

Genty, D., Verheyden, S., and Wainer, K.: Speleothem records over the Last Interglacial, 1, PAGES, 24-25, 2013.

Gewelt, M. and Ek, C.: Les Concrétions Carbonatees des Grottes: aperçu synthetique, Annales de la Société géologique de Belgique, 111, 9-19, 1988.

Gimeno, L., Drumond, A., Nieto, R., Trigo, R. M., and Stohl, A.: On the origin of continental precipitation, Geophys. Res. Lett., 37, L13804, doi:10.1029/2010GL043712, 2010.

Goelzer, H., Huybrechts, P., Loutre, M.-F., and Fichefet, T.: Impact of ice sheet meltwater fluxes on the climate evolution at the onset of the Last Interglacial, Clim. Past Discuss., 11, 4391-4423, doi:10.5194/cpd-11-4391-2015, 2015. 
Hearty, P. J., Hollin, J. T., Neumann, A. C., O’Leary, M. J., and McCulloch, M.: Global sea-level fluctuations during the Last Interglaciation (MIS 5e), Quaternary Sci. Rev., 26, 2090-2112, doi:10.1016/j.quascirev.2007.06.019, 2007.

Helmens, K. F.: The Last Interglacial Glacial cycle (MIS 52) re-examined based on long proxy records from central and northern Europe, Quaternary Sci. Rev., 86, 115-143, doi:10.1016/j.quascirev.2013.12.012, 2014.

Hendy, C. H.: Isotopic geochemistry of speleothems. 1. Calculation of effect of different modes of formation on isotopic compositions of speleothems and their applicability as paleoclimatic indicators, Geochim. Cosmochim. Acta, 35, 801-824, doi:10.1016/0016-7037(71)90127-x, 1971.

Holzkamper, S., Mangini, A., Spotl, C., and Mudelsee, M.: Timing and progression of the Last Interglacial derived from a high alpine stalagmite, Geophys. Res. Lett., 31, L07201, doi:10.1029/2003g1019112, 2004.

Irvali, N., Ninnemann, U. S., Galaasen, E. V., Rosenthal, Y., Kroon, D., Oppo, D. W., Kleiven, H. F., Darling, K. F., and Kissel, C.: Rapid switches in subpolar North Atlantic hydrography and climate during the Last Interglacial (MIS 5e), Paleoceanography, 27, PA2207, doi:10.1029/2011pa002244, 2012.

Jaffey, A. H., Flynn, K. F., Glendenin, L. E., Bentley, W. C., and Essling, A. M.: Precision Measurement of half-lives and specific activities of 235U and 238U, Phys. Rev. C, 4, 1889-1906, 1971.

Kukla, G. J., Bender, M. L., de Beaulieu, J. L., Bond, G., Broecker, W. S., Cleveringa, P., Gavin, J. E., Herbert, T. D., Imbrie, J., Jouzel, J., Keigwin, L. D., Knudsen, K. L., McManus, J. F., Merkt, J., Muhs, D. R., Muller, H., Poore, R. Z., Porter, S. C., Seret, G., Shackleton, N. J., Turner, C., Tzedakis, P. C., and Winograd, I. J.: Last interglacial climates, Quaternary Res., 58, 2-13, doi:10.1006/qres.2001.2316, 2002.

Lachniet, M. S.: Climatic and environmental controls on speleothem oxygen-isotope values, Quaternary Sci. Rev., 28, 412-432, doi:10.1016/j.quascirev.2008.10.021, 2009.

Loutre, M. F., Fichefet, T., Goosse, H., Huybrechts, P., Goelzer, H., and Capron, E.: Factors controlling the last interglacial climate as simulated by LOVECLIM1.3, Clim. Past, 10, 1541-1565, doi:10.5194/cp-10-1541-2014, 2014.

Martinson, D. G., Pisias, N. G., Hays, J. D., Imbrie, J., Moore, T. C., and Shackleton, N. J.: Age dating and the orbital theory of the ice ages: Development of a high-resolution 0 to 300,000-year chronostratigraphy, Quaternary Res., 27, 1-29, doi:10.1016/0033-5894(87)90046-9, 1987.

McDermott, F.: Palaeo-climate reconstruction from stable isotope variations in speleothems: a review, Quaternary Sci. Rev., 23, 901-918, doi:10.1016/j.quascirev.2003.06.021, 2004.

McDermott, F., Atkinson, T. C., Fairchild, I. J., Baldini, L. M., and Mattey, D. P.: A first evaluation of the spatial gradients in delta O18 recorded by European Holocene speleothems, Global Planet. Change, 79, 275-287, doi:10.1016/j.gloplacha.2011.01.005, 2011.

McManus, J. F., Bond, G. C., Broecker, W. S., Johnsen, S., Labeyrie, L., and Higgins, S.: High-resolution climate records from the North Atlantic during the last interglacial, Nature, 371, 326-329, 1994.

Meyer, M. C., Spotl, C., and Mangini, A.: The demise of the Last Interglacial recorded in isotopically dated speleothems from the Alps, Quaternary Sci. Rev., 27, 476496, doi:10.1016/j.quascirev.2007.11.005, 2008.

Moseley, G. E., Spötl, C., Cheng, H., Boch, R., Min, A., and Edwards, R. L.: Termination-II interstadial/stadial climate change recorded in two stalagmites from the north European Alps, Quaternary Sci. Rev., 127, 229-239, doi:10.1016/j.quascirev.2015.07.012, 2015.

NEEM community: Eemian interglacial reconstructed from a Greenland folded ice core, Nature, 493, 489-494, doi:10.1038/nature11789, 2013.

NGRIP members: High-resolution record of Northern Hemisphere climate extending into the last interglacial period, Nature, 431, 147-151, 2004.

Otto-Bliesner, B. L., Rosenbloom, N., Stone, E. J., McKay, N. P., Lunt, D. J., Brady, E. C., and Overpeck, J. T.: How warm was the last interglacial? New model - data comparisons, Philosophical Transactions of the Royal Society A: Mathematical, Phys. Engin. Sci., 371, 1-20, 2013.

Otvos, E. G.: The Last Interglacial Stage: Definitions and marine highstand, North America and Eurasia, Quaternary Int., 383, 158-173, doi:10.1016/j.quaint.2014.05.010, 2015.

Pyankov, V. I., Ziegler, H., Akhani, H., Deigele, C., and Lüttge, U.: European plants with $\mathrm{C} 4$ photosynthesis: geographical and taxonomic distribution and relations to climate parameters, Bot. J. Linn. Soc., 163, 283-304, 2010.

Quinif, Y.: Complex stratigraphic sequences in Belgian caves: correlation with climate changes during the Middle, the Upper Pleistocene and the Holocene, Geologica Belgica, 9, 231-244, 2006.

Quinif, Y. and Bastin, B.: Datation Uranium/Thorium et Analyse Pollinique d'une Séquence Stalagmitique du Stade 5 (Galerie des Verviétois, Grotte de Han-sur-Lesse, Belgique), Comptes Rendus de l'Académie des Sciences, 318, 211-217, 1994.

Rasmussen, S. O., Bigler, M., Blockley, S. P., Blunier, T., Buchardt, S. L., Clausen, H. B., Cvijanovic, I., Dahl-Jensen, D., Johnsen, S. J., Fischer, H., Gkinis, V., Guillevic, M., Hoek, W. Z., Lowe, J. J., Pedro, J. B., Popp, T., Seierstad, I. K., Steffensen, J. P., Svensson, A. M., Vallelonga, P., Vinther, B. M., Walker, M. J. C., Wheatley, J. J., and Winstrup, M.: A stratigraphic framework for abrupt climatic changes during the Last Glacial period based on three synchronized Greenland ice-core records: refining and extending the INTIMATE event stratigraphy, Quaternary Sci. Rev., 106, 14-28, 2014.

Riechelmann, D. F. C., Schroeder-Ritzrau, A., Scholz, D., Fohlmeister, J., Spoetl, C., Richter, D. K., and Mangini, A.: Monitoring Bunker Cave (NW Germany): A prerequisite to interpret geochemical proxy data of speleothems from this site, J. Hydrol., 409, 682-695, 2011.

Rozanski, K., Araguasaraguas, L., and Gonfiantini, R.: Relation between long-term trends of 18-O isotope composition of precipitation and climate, Science, 258, 981-985, doi:10.1126/science.258.5084.981, 1992.

Sánchez Goñi, M. F., Eynaud, F., Turon, J. L., and Shackleton, N. J.: High resolution palynological record off the Iberian margin: direct land-sea correlation for the Last Interglacial complex, Earth Planet. Sci. Lett., 171, 123-137, doi:10.1016/S0012821X(99)00141-7, 1999.

Sánchez Goñi, M. F., Bakker, P., Desprat, S., Carlson, A. E., Van Meerbeeck, C. J., Peyron, O., Naughton, F., Fletcher, W. J., Eynaud, F., Rossignol, L., and Renssen, H.: European climate opti- 
mum and enhanced Greenland melt during the Last Interglacial, Geology, 40, 627-630, doi:10.1130/g32908.1, 2012.

Scholz, D. and Hoffmann, D. L.: StalAge - An algorithm designed for construction of speleothem age models, Quat. Geochronol., 6, 369-382, doi:10.1016/j.quageo.2011.02.002, 2011.

Shackleton, N. J.: Last Interglacial in marine and terrestrial records, Proceedings of the Royal Society Series B-Biological Sciences, 174, 135-154, doi:10.1098/rspb.1969.0085, 1969.

Shen, C. C., Wu, C. C., Cheng, H., Edwards, R. L., Hsieh, Y. T., Gallet, S., Chang, C. C., Li, T. Y., Lam D. D., Kano, A., Hori, M., and Spötl, C.: High-precision and high-resolution carbonate 230Th dating by MC-ICP-MS with SEM protocols, Geochim. Cosmochim. Acta, 99, 71-86, 2012.

Sirocko, F., Seelos, K., Schaber, K., Rein, B., Dreher, F., Diehl, M., Lehne, R., Jager, K., Krbetschek, M., and Degering, D.: A late Eemian aridity pulse in central Europe during the last glacial inception, Nature, 436, 833-836, 2005.

Soreng, R. J., Peterson, P. M., Romaschenko, K., Davidse, G., Zuloaga, F. O., Judziewicz, E. J., Filguieras, T. S., Davis, J. I., and Morrone, O.: A worldwide phylogenetic classification of the Poaceae (Gramineae), J. Syst. Evolution, 53, 117-137, 2015.

Timperman, M.: La Grotte de Han: Au Fil de Siècles, Gembloux, 66 pp., 1989.

Tzedakis, P. C., Frogley, M. R., and Heaton, T. H. E.: Last Interglacial conditions in southern Europe: evidence from Ioannina, northwest Greece, Global Planet. Change, 36, 157-170, doi:10.1016/S0921-8181(02)00182-0, 2003.

van Kreveld, S., Sarnthein, M., Erlenkeuser, H., Grootes, P., Jung, S., Nadeau, M. J., Pflaumann, U., and Voelker, A.: Potential links between surging ice sheets, circulation changes, and the Dansgaard-Oeschger Cycles in the Irminger Sea, 60-18 Kyr, Paleoceanography, 15, 425-442, doi:10.1029/1999PA000464, 2000.

Van Rampelbergh, M., Verheyden, S., Allan, M., Quinif, Y., Keppens, E., and Claeys, P.: Monitoring of a fast-growing speleothem site from the Han-sur-Lesse cave, Belgium, indicates equilibrium deposition of the seasonal $\delta^{18} \mathrm{O}$ and $\delta^{13} \mathrm{C}$ signals in the calcite, Clim. Past, 10, 1871-1885, doi:10.5194/cp-10-1871-2014, 2014.

Van Rampelbergh, M., Verheyden, S., Allan, M., Quinif, Y., Cheng, H., Edwards, L. R., Keppens, E., and Claeys, P.: A 500-year seasonally resolved $\delta^{18} \mathrm{O}$ and $\delta^{13} \mathrm{C}$, layer thickness and calcite aspect record from a speleothem deposited in the Han-sur-Lesse cave, Belgium, Clim. Past, 11, 789-802, doi:10.5194/cp-11-7892015, 2015.
Verheyden, S.: The $8.2 \mathrm{ka}$ event: is it registered in Belgian speleothems?, Speleogenesis and Evolution of Karst Aquifers, 3-8, 2012.

Verheyden, S., Baele, J. M., Keppens, E., Genty, D., Cattani, O., Hai, C., Edwards, L., Hucai, Z., Van Strijdonck, M., and Quinif, Y.: The proserpine stalagmite (Han-sur-Lesse Cave, Belgium): Preliminary environmental interpretation of the last 1000 years as recorded in a layered speleothem, Geologica Belgica, 9, 245256, 2006.

Verheyden, S., Genty, D., Deflandre, G., Quinif, Y., and Keppens, E.: Monitoring climatological, hydrological and geochemical parameters in the Pere Noel cave (Belgium): implication for the interpretation of speleothem isotopic and geochemical time-series, Int. J. Speleol., 37, 221-234, 2008.

Verheyden, S., Keppens, E., Quinif, Y., Cheng, H. J., and Edwards, L. R.: Late-glacial and Holocene climate reconstruction as inferred from a stalagmite - Grotte du Pere Noel, Han-sur-Lesse, Belgium, Geologica Belgica, 17, 83-89, 2014.

Waelbroeck, C., Labeyrie, L., Michel, E., Duplessy, J. C., McManus, J. F., Lambeck, K., Balbon, E., and Labracherie, M.: Sealevel and deep water temperature changes derived from benthic foraminifera isotopic records, Quaternary Sci. Rev., 21, 295-305, doi:10.1016/s0277-3791(01)00101-9, 2002.

Wainer, K., Genty, D., Blamart, D., Bar-Matthews, M., Quinif, Y., and Plagnes, V.: Millennial climatic instability during penultimate glacial period recorded in a south-western France speleothem, Palaeogeogr. Palaeoclimatol. Palaeoecol., 376, 122131, doi:10.1016/j.palaeo.2013.02.026, 2013.

Wang, Y. J., Cheng, H., Edwards, R. L., An, Z. S., Wu, J. Y., Shen, C. C., and Dorale, J. A.: A High-Resolution Absolute-Dated Late Pleistocene Monsoon Record from Hulu Cave, China, Science, 294, 2345-2348, 2001.

Wohlfarth, B.: A review of Early Weichselian climate (MIS 5d-a) in Europe, Swedish Nuclear Fuel and Waste Management Co, 2013.

Woillard, G. M.: Grande Pile peat bog: A continuous pollen record for the last 140,000 years, Quaternary Res., 9, 1-21, doi:10.1016/0033-5894(78)90079-0, 1978.

Yuan, D., Cheng, H., Edwards, R. L., Dykoski, C. A., Kelly, M. J., Zhang, M., Qing, J., Lin, Y., Wang, Y., Wu, J., Dorale, J., An, Z., and Cai, Y.: Timing, Durqtion and Transition of the Last Interglacial Asian Monsoon, Science, 304, 575-578, 2004. 